\title{
DAMPAK GEMPA BUMI TERHADAP LINGKUNGAN HIDUP
}

\author{
Oleh: Dadang Sungkawa*)
}

\begin{abstract}
ABSTRAK
Berbicara tentang gempa bumi adalah hal yang menarik saat ini untuk dibahas, karena seringkali wilayah Indonesia dilanda gempa bumi. Banyak masyarakat Indonesia sebelum tahun 2000 belum mengenal fakta empiris dari kejadian suatu gempa bumi, hal ini karena keterbatasan berita melalui media massa dan media elektronik. Namun sejak tahun 2000-an dengan banyaknya penyajian berita melalui saluran TV swasta maka berita tentang gempa bumi langsung dapat disaksikan oleh para pemirsa TV. Demikian juga dengan konsep " tsunami". Tsunami merupakan gelombang besar yang melanda pantai-pantai di Jepang setelah terjadinya gempa di dasar laut. Tsunami dapat menimbulkan korban harta benda dan jiwa. Tsunami saat itu belum banyak dilihat faktanya. Konsep gempa bumi dan tsunami baru menjadi fakta empiris bagi masyarakat Indonesia umumnya ketika terjadi gempa bumi di Aceh dan Sumatera Utara tanggal 26 Desember 2004, Gempa bumi di Yogyakarta 27 Mei 2006, gempa bumi dan tsunami di Pangandaran masih di tahun 2006, gempa bumi di Bengkulu dan terakhir gempa bumi di Sumatera Barat 6 maret 2007.
\end{abstract}

Kata kunci: Gempa bumi, tsunami.

\section{Pendahuluan}

Dilihat dari karakteristiknya ada 3 macam gempa bumi, yaitu Gempa bumi runtuhan, adalah gempa bumi yang disebabkan oleh runtuhnya lubang-lubang interior bumi, misalnya runtuhnya lorong tambang dan lorong sebuah gua. Gempa bumi ini adalah yang paling kecil getarannya; Gempa bumi vulkanik, adalah gempa bumi akibat aktivitas gunung api, yaitu akibat gerakan magma dari dalam bumi (batholit) yang naik ke atas (lubang kepundan). Gerakan magma ini menimbulkan getaran-getaran gempa yang dapat di rasakan oleh masyarakat di sekitar gunung api sebelum gunung tersebut meletus. Getaran gempa ini relatif kecil pengaruhnya kepada penduduk, yang merusak justru letusan gunung api itu sendiri yang memuntahkan lava, lahar, batu, pasir, abu dan gas vulkanik; Gempa bumi tektonik, adalah gempa yang terjadi karena pelepasan tenaga akibat pergeseran sesar atau kekenyalan elastis pada daerah tumbukan lempeng samudra dengan lempeng benua. Di Indonesia umumnya daerah tumbukan dan retakan lempeng merupakan pusat (hiposentrum) gempa di dalam bumi yang dirambatkan ke permukaan bumi (Episentrum) yang selanjutnya menimbulkan getaran-getaran gempa di permukaan bumi.

*) Drs. H. Dadang Sungkawa, M.Pd., adalah dosen Jurusan Pendidikan Geografi FPIPS UPI. 
Dewasa ini gempa bumi tektonik merupakan fenomena alam yang sering terjadi di Indonesia. Gempa bumi tektonik merupakan peristiwa pelepasan energi regangan elastis batuan di dalam bumi. Semakin besar energi yang dilepaskan akan semakin kuat gempa yang terjadi. Ada dua teori yang menyatakan timbulnya gempa bumi, yang pertama disebabkan oleh pergeseran sesar dan yang kedua disebabkan oleh lepasnya energi kekenyalan elastis. Gerak tiba-tiba sepanjang sesar merupakan penyebab sering terjadinya gempa.

Gempa bumi sebenarnya terjadi setiap saat atau setiap hari di bumi, namun kebanyakan gempa yang terjadi kekuatannya kecil sehingga tidak terasa oleh penduduk dan tidak menyebabkan kerusakan apa-apa. Tetapi gempa bumi kecil ini bisa juga merupakan gempa awal yang disusul dengan gempa bumi besar atau boleh juga sebagai gempa akhir setelah gempa besar yang disebut gempa bumi susulan.

Gempa bumi yang getarannya sangat kuat dapat menyebabkan kerusakan di permukaan bumi, yaitu berupa hancurnya bangunan, rumah, fasilitas umum dan jatuhnya korban jiwa. Gempa jenis inilah yang paling kuat menguncang permukaan bumi seperti yang terjadi di Aceh dan Sumatera Utara (8,9 Skala Richter) Yogyakarta (6,2 skala Richter) dan Sumatera Barat (5,8 skala Richter).

\section{Dampak Gempa Bumi Terhadap Lingkungan}

Gempa bumi merupakan fenomena alam yang sukar sekali untuk diramalkan kapan terjadinya, berapa kekuatan gempanya, apakah gempa yang terjadi menimbulkan kerusakan harta benda dan menimbulkan korban jiwa atau tidak. Karena kesulitan dalam memprediksi gempa itu maka apabila terjadi gempa yang merusak (lebih dari 5 Slaka Richter) maka akan menimbulkan stress dan schok berat terhadap penduduk yang terkena gempa tersebut, sebab betapa tidak setiap orang di daerah gempa tersebut dalam sekejap waktu bisa kehilangan segala-galanya, seperti kehilangan keluarga dan harta benda.

Dilihat dari karakteristiknya ada dua penyebab bahaya dari gempa bumi, yaitu pertama karena goyangan langsung dari getaran yang terjadi di permukaan bumi, yang kedua karena terjadinya tsunami akibat getaran gempa di dalam laut yang menyebabkan gelombang besar yang menghantam daratan pantai tempat pemukiman dan aktifitas penduduk.

Getaran gempa yang memiliki kekuatan gempa di atas 5 Skala Richter menyebabkan terjadinya getaran di permukaan bumi, getaran ini menggoyang benda-benda di atasnya seperti rumah-rumah, perabotan rumah, bangunan, tiang listrik, pohon dan sebagainya. Bila benda-benda tersebut tidak kuat menahan getaran maka akan rubuh, tumbang, terpelanting dan jatuh. Korban jiwa akan terjadi bila benda-benda tesebut menimpa orang-orang yang berdekatan dengan benda-benda yang jatuh atau terpelanting karena gempa bumi. Fakta empiris dari suatu gempa bumi dapat kita saksikan misalnya akibat dari gempa di Yogyakarta (6,2 Skala Richter) dan Sumatera Barat (5,8 Skala Richter) memperlihatkan banyak rumah dan bangunan yang hancur, sarana dan prasarana umum rusak berat.

Tsunami yang terjadi setelah gema bumi di dasar laut menimbulkan gelombang besar yang menghantam daratan pantai. Fakta empirisnya dapat kita saksikan setelah gempa bumi yang melanda Aceh dan Sumatera Utara (8,9 Skala Richter). Gelombang besar setinggi 10 meter menghantam kota Banda Aceh, 
Lhokseumawe, Pulau Nias dan sekitarnya. Gelombang besar ini meluluhlantahkan pemukiman penduduk, sarana-prasarana serta fasilitas umum yang ada. Lingkungan di sini rusak berat dan hancur total. Ini merupakan kerusakan lingkungan akibat gempa dan tsunami di Indonesia yang paling besar di abad 21 . untuk memulihkan lingkungan tersebut perlu pembangunan dan rehabilitasi bertahun-tahun dengan dana yang tidak sedikit. Demikian juga tsunami yang melanda Pangandaran (Juni 2006) dalam hitungan menit sarana dan prasarana pariwisata di daerah ini mengalami kehancuran, sehingga perlu waktu dan dana yang tidak sedikit untuk membangun kembali lingkungan hidup di daerah ini.

\section{Lingkungan di Indonesia yang Rawan Gempa}

Berdasarkan catatan sejarah gempa bumi, Indonesia merupakan wilayah yang sering dilanda gempa bumi dan tsunami. Setelah meletusnya G. Krakatau yang menimbulkan tsunami besar tahun 1883, sedikitnya telah terjadi 19 kali bencana tsunami besar di Indonesia selama lebih dari satu abad (1900 - 2006). Gempa Bumi dan tsunami besar yang terakhir terjadi pada 26 Desember 2004 di Aceh dan sebagian Sumatera Utara. Lebih dari 150.000 orang meninggal dunia. Setelah itu menyusul gempa di Nias tahun 2005, 1000 orang menjadi korban. 27 Mei 2006 Yogyakarta dan sebagian Jawa Tengah juga di landa gempa bumi, korban meninggal mencapai 6500 orang lebih. Masih dalam tahun 2006 juga tsunami besar melanda wilayah Pangandaran Jawa Barat yang menyebabkan kerusakan pemukiman penduduk, sarana dan prasana pariwisata di daerah ini. Rupanya bencana bagi bangsa Indonesia tidak habis sampai di situ, gempa bumi tektonik juga melanda Sumatera Barat pada Tanggal 6 Maret 2007, laporan terakhir menyatakan 79 orang tewas.

Berbagai dearah di Indonesia sangat rawan akan bencana gempa bumi dan tsunami. Wilayah Indonesia dikelilingi oleh lempeng Eurasia, lempeng Indo Australia dan lempeng Pasifik. Setiap saat lempeng ini akan bergeser dan bergerak menimbulkan gempa bumi. Gerakan gempa yang terjadi di dasar laut dapat mengguncangan massa air laut dan menimbulkan terjadinya tsunami.

Menurut Direktorat Vulkanologi dan Mitigasi Bencana Geologi (DVMBG) Departemen Energi dan Sumber Daya Mineral tercatat ada 28 Wilayah di Indonesia yang dinyatakan rawan gempa bumi dan tsunami diantaranya : Nagroe Aceh Darusalam, Sumatera Utara, Sumatera Barat, Bengkulu, Lampung, banten, Jawa Tengah, Daerah Istimewa Yogyakarta bagian Selatan, Jawa Timur bagian Selatan, Bali, Nusa Tenggara Barat, Nusa Tenggara Timur, Sulawesi Utara, Sulawesi Tengah, Sulawesi Selatan, Maluku Utara, Maluku Selatan, Biak, Yapen dan Fak - Fak di Papua, dan Balikpapan di Kalimantan Timur.

Selain dikelilingi tiga lempeng tektonik dunia, Indonesia juga merupakan jalur The Pasific Ring of Fire (Cincin Api Pasifik) yang merupakan jalur rangkaian gunung api aktif di dunia. Indonesia memiliki gunung berapi kurang lebih 240 buah, diantaranya 70 buah masih aktif. Zone kegempaan dan gunung api aktif Sirkum Pasifik amat terkenal karena setiap gempa kuat atau tsunami hebat di kawasan ini dipastikan menelan korban jiwa manusia amat banyak

Kita sebagai manusia biasa sulit memprediksi gempa bumi yang akan terjadi karena gempa dapat terjadi secara tiba-tiba karena itu yang masih mungkin di lakukan adalah melakukan sistem peringatan dini (Early Warning System) yang berfungsi sebagai "alarm" darurat jika sewaktu-waktu datang gempa. Implementasi 
sistem ini bisa diterapkan dengan memasang rangkaian seismograph yang tersambung dengan satelit. National Ocean and Atmospheric Administration (NOAA) USA misalnya, telah menggunakan sensor DART (Deep Ocean Assesment and Reporting) yang mampu mengukur perubahan gelombang laut akibat gempa bumi tektonik.

Preliminary Determination of Epicenters 358,214 Events, 1963 - 1998

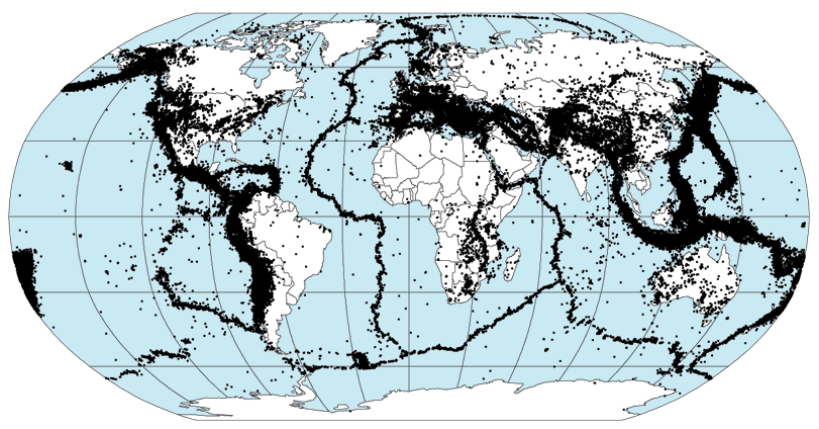

Alat - alat pendeteksi gempa harus diletakan pada daerah-daerah rawan gempa seperti Aceh, Nabire, Alor, Bengkulu pantai Selatan Jawa, dan sejumlah daerah rawan gempa lainnya. Alat-alat pendeteksi dipasang dan dipantau setiap hari oleh petugas teknis yang berada di daerah yang bersangkutan. Data yang diperoleh dikirim ke pusat untuk diolah dan dianalis oleh para pakar gempa untuk memprediksi secara dini kapan gempa akan terjadi.

\section{Persiapan Menghadapi Gempa Bumi}

Bagi penduduk yang tinggal di daerah rawan gempa, perlu mempersiapkan diri dalam menghadapi gempa bumi agar selamat dan mampu mengatasi musibah akibat bencana gempa ini. Persiapan yang dilakukan terbagi menjadi dua macam, yaitu persiapan untuk keadaan darurat dan persiapan ketika terjadi gempa bumi.

\section{a. Persiapan untuk Keadaan Darurat}

(1) Menentukan tempat-tempat berlindung yang aman jika terjadi gempa. Tempat berlindung yang aman di dalam rumah adalah kolong meja yang dapat melindungi anda dari benda-benda yang jatuh atau mebel yang ambruk.

(2) Menyediakan air minum secukupnya.

(3) Menyiapkan tas yang berisi barang-barang yang sangat di butuhkan dalam pengungsian, seperti: lampu senter, air minum, kotak P3K yang berisi obat-obat yang dibutuhkan, makanan tahan lama (biskuit), Sejumlah uang tunai, buku tabungan, korek api, lilin, helm, pakaian, barang-barang berharga yang harus di bawa (perhiasan).

(4) Mengencangkan mebel yang mudah rubuh bila terjadi gempa. 
(5) Mencegah kaca jendela atau kaca lemari pakaian agar tidak pecah saat gempa bumi dengan menempelkan kaca film atau menggunakan safety glass.

(6) Mencari tahu lokasi tempat evakuasi dan rumah sakit terdekat. Jangan evakuasi ke tempat yang rendah seperti pinggir laut atau sungai untuk menghindari tsunami.

\section{b. Persiapan Ketika terjadi Gempa}

(1) Matikan api kompor jika anda sedang memasak, matikan juga alat-alat elektronik yang dapat menyebabkan timbulnya api. Jika terjadi kebakaran segera padamkan api dengan alat pemadam api, pasir atau karung basah.

(2) Membuka pintu dan mencari jalan keluar dari rumah atau gedung.

(3) Utamakan keselamatan terlebih dahulu, jika terjadi kerusakan pada tempat anda berada segera mengungsi ke tempat pengusian terdekat.

(4) Tetap tenang dan tidak terburu-buru ke luar dari rumah atau gedung. Tunggu sampai gempa mereda, ambil tas yang berisi barang-barang keperluan darurat barulah ke luar rumah atau gedung menuju tanah kosong/ lapang sambil melindungi kepala dengan helm atau barang-barang yang bisa melindungi kepala.

(5) Pastikan tidak ada anggota keluarga yang tertinggal pada saat evakuasi. Jika bisa ajaklah tetangga dekat untuk evakuasi.

(6) Jika gempa bumi terjadi saat anda sedang menyetir kendaraan, kurangi kecepatan kendaraan, dan hentikan kendaraan di bahu jalan. Jangan berhenti di dekat pompa bensin, di bawah kabel tegangan tinggi, di jembatan, atau di bawah jembatan.

(7) Cari informasi mengenai gempa bumi yang terjadi lewat media massa.

\section{Penutup}

Seperti sudah dikatakan sebelumnya oleh penulis bahwa sebagai manusia biasa kita sulit memprediksi dan meramal kapan gempa bumi akan terjadi, karena gempa merupakan peristiwa alam yang sudah diprogram oleh Yang Maha Pencipta, gempa bumi merupakan sunatullah sama halnya dengan peristiwa alam lainnya seperti terjadinya angin, hujan, badai dan petir. Namun sebagai mahluk yang diberikan kepandaian berpikir oleh Allah kita sebagai manusia tentu dapat mengatasi gempa bumi ini dengan menyesuaikan diri (adaptasi) dengan daerah lingkungan gempa bumi seperti memiliki ilmu pengetahuan tentang gempa bumi, persiapan diri menghadapi gempa bumi yang bisa terjadi sewaktu-waktu, memilih pekerjaan dan aktifitas yang sesuai dengan daerah gempa dan memiliki rumah yang kontruksinya cocok untuk daerah gempa. Demikian juga pemerintah pusat dan daerah mampu membangun sarana dan prasarana umum, lingkungan kerja dan lingkungan pemukiman yang sesuai dengan daerah gempa. Lembagalembaga yang terkait seperti DVMBG yang menangani masalah kegempaan mampu memanfaatkan temuan-temuan di bidang ilmu pengetahuan dan teknologi untuk kepentingan masyarakat. Demikian juga media massa mampu memberikan informasi dan keterangan tentang gempa bumi yang bermanfaat bagi masyarakat.

Bagi orang-orang atau penduduk yang tidak mampu beradaptasi di daerah rawan gempa silahkan pindah dan tinggal di daerah yang aman dari gempa, wilayah Indonesia masih luas, jangan tinggal di 28 wilayah rawan gempa dan 
tsunami menurut DVMBG yang telah di kemukaan oleh penulis pada bagian 3 . Sebagai manusia hidup kita di dunia ini sangat singkat, kita harus mampu menggunakan akal dan pikiran kita untuk berusaha dan memilih jalan hidup yang terbaik, selanjutnya tawakalah kepada Allah. Semoga kita terhindar dari bencana gempa bumi dan tsunami, Amin.

\section{Daftar Pustaka}

Dadang Sungkawa. 2007. Geografi Regional Indonesia. Jurusan Pendidikan Geografi FPIPS UPI Bandung.

Ensiklopedi Indonesia Seri Geografi, Indonesia. 1996. Jakarta: PT Ichtiar Baru Van Hoeve.

I Made Sandy. 1985. Republik Indonesia. Geografi Regional, Jurusan Geografi FMIPA Universitas Indonesia.

Sudjiran Resosudarmo. 1975. Ilmu Bumi Alam. Bandung: N.V. Masa Baru.

Sukendar Asikin. 1991. Geologi Struktur Indonesia. Laboratorium Geologi Dinamis - Geologi ITB.

Wardiyatmoko. 1989. Geografi. Jakarta: Erlangga. 